your readers may have gathered, I held the office of housesurgeon for six months, at the end of which time I was offered an additional three months, which $I$ accepted, knowing that the same reward had within the last four years twice been offered to gentlemen who were in no way connected with the staff. To the former of these Mr. Heckford alludes, "to prevent a quibble," as he says, but suppresses the most important circumstance, that the gentleman in question was actually recommended by the surgical staff to the committee for reappointment, but that the latter body refused to accept him on account of his having been guilty of a breach of regulations. In the latter case Mr. Dove was re-elected, and held office for an additional period of two months, without any objection. Now whether these facts were known to Mr. Heckford or not, his assertions are equally unjustifiable ; but I distinctly recollect telling him, in the presence of witnesses, the true state of the case concerning the first instance I have cited, and he was also reminded of the second. In addition, I may inform $\mathrm{Mr}$. Heckford, and the public generally, that, according to the standing orders, "the office of house-surgeon is renewable every three months, subject to the limitation that the office shall not be held by the same individual for a period exceeding two years."

With regard to my appointment as medical registrar (which I resigned last year, knowing that Mr. Heckford would be a candidate for it), he must be aware that I did not seek the post until I was assured that no other student of the hospital of equal standing with myself desired it, and that I then ventured to oppose a gentleman far superior to myself, because he had previously been unconnected with the hospital, that the office might still remain within the reach of our own students.

Mr. Heckford's knowledge of the history of this institution "for the last ten years" appears to be decidedly hazy, but ignorance can be no cloak for inaccurate statements made by a disinterested champion of a great cause. I am the son of the senior strgeon, but I am also a perpetual student : why may I not have the same privileges extended to me that are granted to others? I have neither asked nor obtained more, and there are some who have held more appointments than I, and justly so, because their general attainments have been superior to mine.

To avoid the possibility of an insinuation of favouritism I did not present myself as a candidate for the surgical gold medal, and so lost a chance (however remote) of being able to advertise the double distinction, which Mr. Heckford and Mr. Walker have, with questionable taste, taken a recent opportunity of doing.

Aug. 1867.

I am, Sir, yours truly,

* Several other letters have been received on this painful subject. The amount of space we have already given to it evinces our desire to afford full publicity to the explanations from both parties in the dispute. The various points of disagreement have now been placed sufficiently in detail before the profession, and the demands on our space compel us to limit the discussion. Next week a letter from Mr. Heckford, in which he makes certain suggestions in the way of reform for the consideration of the Council of the London Hospital, and another, containing a personal explanation from Mr. Robinson, will appear in our columns; after which the official reply of Mr. Hutchinson, as the dean of the school, must end the controversy.- $-\mathrm{E}_{\mathrm{D}} \mathrm{L}$.

\section{CRAMMING FOR EXAMINATIONS.} To the Editor of THE LANCET.

Sir,-The Lardet of the 11th of May last contains a letter from Mr. Busk commenting on certain statements made by me-with reference to the Chelsea competitive examinationin an article "On Army Reorganisation" in the United Service Magazine for March, 1867. In concluding his remarks Mr. Busk states :-

" Dr. Rennie is further of opinion, as may be gathered from the following curious sentence, that if the examination were done away with 'the army would become a prize for the best of students, and be relieved from the approbation which of late has began to be attached to it in the medical periodicals of being a place of refuge for the sweepings of the medical schools, It is to be hoped that this beginning will not be followed up, and I think few will be found to concur with Dr.
Rennie in the opinion that the system of competitive examination for entry into the service should be abolished."

Those who read the magazine referred to may have observed, from a letter addressed by me to the editor (in the number for May of the present year), that in writing from a remote part of India I labour under the disadvantage of not seeing "proof sheets," and consequently of being unable myself to correct typographical errors; and as Mr. Busk has quoted what is certainly a curious sentence, I have to ask the favour of your giving insertion to the following-namely, the sentence in question as originally written by me, also the context as published in the United Service Magazine, the same being neces. sary to render intelligible the expression of opinion cited by Mr. Busk :-

" Having casually alluded to the exception taken by the medical schools of the United Kingdom to the medical service of the army, it appears to me that grounds exist for identifying these schools more with the Army Medical Department than has yet been done, by holding them more responsible for the class of medical officers entering the army than it has yet been practicable to do, and thus counteract the evils of the vicious system of cramming for special examinations, to which I have endeavoured to draw attention. Either such examinations are unnecessary, or such grave defects exist in the present system of medical education as to justify the belief that the legal qualification to practise medicine and surgery is a mere licence, in many instances, to trifle with health and life; because it stands to common sense, that if 'qualified medical practitioners' are not fit to treat British soldiers without being specially tested, they must be certainly equally unfit to treat her Majesty's ordinary, but apparently less fortunate, subjects. Such at least is the unvarnished conclusion that the present system of examining and re-examining medical candidates inevitably leads to. That the present plan of competitive examination is a bad one there is but little doubt, and were a commission appointed to inquire into its workings and take the evidence of military and medical officers competent to give opinions on the subject, I do not think that a single fact could be adduced in support of it, that a stronger one could not be urged against it. The remedy, in my opinion, for the present unsatisfactory state of matters, is a return, in an altered form, to the patronage system, by throwing the filling up of vacancies in the Army Medical Department entirely into the hands of the licensing medical schools of the country, according to a regulated proportion and roster. Were this done, the army would become a prize for the best of students, and be relieved from the opprobrium which of late has begun to be attached to it in the medical periodicals, of being a place of refuge for the 'sweepings of the medical schools'-language, however, it is to be hoped, more vigorous than accurate.

I am, Sir, your obedient servant,

$$
\text { Campbellpore, June 29th, 1867. } \quad \text { D. F. RENNIE, M.D., }
$$

\section{REVACCINATION OF PREGNANT WOMEN. To the Editor of THE LANCET.}

SIR,-In your notice of the proceedings of the Obstetrical Society of London, on the $27 \mathrm{th}$ ult., Dr. Madge is reported to have suggested "the necessity or advisability of vaccinating or revaccinating all pregnant women during epidemics of small-pox, so as to extend the protective influence of vaccination through the blood of the mother to the child in utero." Such advice is so much at variance with the practice in general use, and, if adopted, may be productive of so much mischief, that I cannot forbear quoting the remarks of Dr. Meigs (Philadelphia) on this subject. He says: "Pregnant women ought not to be vaccinated. This is a rule that $I$ advise you to depart from only on the most urgent occasions. If a woman have been once vaccinated, and appeal to you to revaccinate her, because there is a present variolous epidemic, I hope you will refuse to accede to her request. Small-pox is exceedingly and peculiarly pernicious to pregnant women. She who has it, and miscarries, or who is brought to bed at term, generally dies. It is, in my opinion, inexcusable to expose her to so great a risk, a risk far greater than that from accidental contagion, or that of the epidemy. But the vaccine is identical with the variolous animal poison, saving some lessened intensity of its malignant form, derived from its having been modified by the nature of another mammal. To inoculate a cow with small-pox virus, is to give her the vaccine disease, with the lymph of which you can vaccinate, but not reproduce unmodi: 